\title{
Afterword. Going Granular
}

\author{
Javier Auyero $^{1}$
}

Accepted: 2 June 2021 /Published online: 18 June 2021

(C) The Author(s), under exclusive licence to Springer Science+Business Media, LLC, part of Springer Nature 2021

\begin{abstract}
The articles in this special issue demonstrate that ethnography is an unparalleled way of penetrating and making sense of what the state is and does, of how ordinary citizens think and feel about it and, in the process, perpetuate and/or challenge existing relationships with it.
\end{abstract}

Keywords Political ethnography $\cdot$ State $\cdot$ Granularity

"The point is that by simply spending time with people, being at their sides as they encounter challenging situations - by hanging out, in other words - you learn a lot more about them than you might by only conducting interviews. By eating with them, traveling with them, breathing their air, you get more than just information. You gain shared experience. And often you get powerful true stories." Ted Conover (2016)

All sorts of memorabilia lined the walls of Manuel's modest house. He is one of the political brokers featured in Uruguayan sociologist María José Álvarez-Rivadulla's insightful account of squatting in her native Montevideo (Álvarez-Rivadulla 2017). A picture of Manuel with left-wing former president, Tabaré Vazquez, was the centerpiece of his "peculiar gallery." The portrait, writes Álvarez-Rivadulla in one of the many passages of "immersive writing" (Conover 2016) sprinkled throughout her book,

was surrounded by a host of newspaper clippings of articles about the neighborhood and a picture of Mario Carminatti, once candidate for city mayor from the traditional centerright Colorado Party. There was another picture of Manuel, this time with Jorge Zabalza, a former city councilor, who lives in a squatter settlement, politically located to the left of the left, once a member of the Tupamaros guerrilla movement, and who has helped and promoted the creation of many settlements in the city. Perhaps the most surprising

Javier Auyero

auyero@austin.utexas.edu

1 Department of Sociology, University of Texas at Austin, 305 E 23rd Street, A1700, Austin, TX 78712-1086, USA 
trophy of all, was a letter in a golden frame...(s)igned by the then President Julio María Sanguinetti, from the Colorado Party, it congratulated Manuel for the 'thriving human group that moves this neighborhood ahead' (139).

Álvarez-Rivadulla uses this vignette to illustrate the deep, complex, and ambiguous connection between squatters and the political system. She does not simply tell readers about the imbrication of collective contentious action, parties, and the state. She shows it to us with an impressive level of ethnographic detail.

Others might dismiss this as merely colorful anecdotal evidence. Not the contributors to this fabulous special issue. They all share with Álvarez-Rivadulla the sensibility - because that is what it ultimately is - towards the fine-grained details of political life. It is in those details - in the seemingly circumstantial interactions of ordinary folks with a street-level bureaucrat, with an officer, with a movement organizer, with a health-care worker, with a political broker, with a fellow squatter - where answers to the more general questions of political sociology - how does domination work? how is legitimacy achieved? what is the state? - are to be found. As contributors to this special issue implicitly argue by way of demonstration: go granular, stay close to the rough ground of politics, and fascinating political dynamics will be unearthed.

In 2006, while I was editor of Qualitative Sociology, I put together a special issue on political ethnography (Auyero 2006). I noticed then that ethnography was not a common methodological tool among those whose profession is defined by the study of politics, i.e. political scientists. Back then, very few articles in mainstream political science journals relied on ethnographic methods. In pure numerical terms, things have not changed that much since then. Between 2011 and 2020, out of 611 articles published in the American Journal of Political Science, only two used ethnographic methods. Things are only marginally better in the American Political Science Review (six out of 517 papers published in that period draw upon ethnography). Looking back further, between 1996 and 2005, out of 938 articles published in both mainstream journals, only one used ethnography.

But ethnographers know better than to trust only numbers. Numbers provide a baseline but not the complete picture. It is certainly true that in many other journals and in book form, political scientists are recognizing ethnography as a legitimate data production technique to study politics (Schatz 2013; Wedeen 2015). So much so that some speak of an "ethnographic turn" in the discipline (Brodkin 2017, 131). Others (Longo and Zacka 2019, 1066) state that "after being out of favor for decades, ethnographic methods are making a comeback in the discipline." This is indeed welcome; after all, as the articles in this special issue clearly demonstrate, ethnography is uniquely equipped to look microscopically at the foundations of political institutions and their attendant sets of practices. Moreover, it is ideally suited to explain why political actors behave the way they do and to identify the causes, processes, and outcomes that are part and parcel of political life. Political scientist Evelyn Brodkin (131) puts it this way: ethnographic research allows us to "learn how political life and possibilities are shaped in quotidian worlds that are beyond the sight of others. It also provides an opportunity to give recognition to these worlds and those whose political realities and interests may otherwise be unseen and unheard. This is the prospect - and the challenge - that lies beyond the computer screen, out in the world where politics lives and breathes in everyday life." Sociologists who study politics have recognized this for a while now. Among them, ethnography is alive and well (Arias 2009; Baiocchi et al. 2013; Elcioglu 2020; Eliasoph 2013; Lapegna 2016; Lichterman 2020; Parvez 2017; Perez 2018a; 2018b; Tarlau 2019). 
The articles in this special issue demonstrate that ethnography - here understood as that "social research based on the close-up, on-the-ground observation of people and institutions in real time and space, in which the investigator embeds herself near (or within) the phenomenon so as to detect how and why agents on the scene act, think and feel the way they do" (Wacquant 2003, 6) - is an unparalleled way of penetrating and making sense of what the state is and does, of how ordinary citizens think and feel about it and, in the process, perpetuate and/or challenge existing relationships with it.

The ethnographic texts I most enjoy reading (and teaching) are those that have a clearly delineated puzzle to be solved or an enigma to be uncovered - a riddle that current scholarship on the topic doesn't seem to be able to explain or understand (Jensen and Auyero 2019). With intriguing puzzles, the articles in this special issue pique our curiosity and then quench it with theoretically-informed ethnographic analyses: How and why are squatters evicted when all the social and political circumstances would lead observers to believe they would not be? And, vice versa, how and why do they get to stay in place when everything would lead us to predict that they would be removed? How and why do pro-democracy citizens turn, in the name of order and discipline, into staunch supporters of authoritarianism? How come the "holy grail" of protected legal status sought after by thousands of refugees is not what they (and we) expect it to be? How and why do global health programs translate into certain embodied practices and self-understandings and, in turn, engender particular forms of contention? How and why are some forms of highly localized collective action more effective than others among equally marginalized and stigmatized groups? How and why does the state manage to keep vulnerable, underpaid, and undervalued women working on its behalf? How and why do those seeking shelter get entangled, more or less contentiously, with a state that never quite delivers on its promises?

All of these articles deal with variations of how the state - as an order, as an idea, as a process - appears in the daily lives of ordinary people. "[T]he state as an institution," write anthropologists Sharma and Gupta $(2006,11)$, "is substantiated in people's lives through the apparently banal practices of bureaucracies" (original emphasis). Much like "winks to epistemology, or sheep raids to revolution," these banal practices speak to larger issues "because they are made to" (Geertz 2017, 23). But they only "speak" if they are interrogated with a set of theoretically informed questions (Bourdieu et al. 1991). And they speak in more nuanced and complex ways if we go granular with them.

People experience the state while they wait in line for a welfare benefit (Auyero 2012), attend a court hearing (Desmond 2017) or a local council meeting (Sullivan 2018), when they squat, obtain housing, apply for legal status, work as one of its (barely compensated) agents, etc. These lived experiences, contributors show us, matter not only because they make the state; they also sometimes serve as the basis for making claims on it and/or challenging the way it works.

Carefully constructing new sociological objects to further unveil the intricate workings of power, the articles here are a treat for readers - not just for their substantive lessons about political experiences, practices, and relations but also, and as importantly, for the ethnographic detail they unearth. They not only show that political ethnography is a vibrant arena of inquiry; they also serve the social sciences in pondering the adequacy of their conceptual tools (and their continual reliance on stylized facts) - and in refining them, vis-à-vis fine-grained description.

So, where do we go from here? I am not fond of agenda-setting papers - I think research programs tend to grow organically out of collective work, much improvisation, and not few 
failed attempts. Yet, the essays in this special issue demonstrate the virtues and potential of political ethnography - a detailed, immersive way of looking that is sorely needed these days. There is little doubt that the COVID-19 pandemic has brought renewed attention to the state (what it is, what it does, what it should do to protect its citizens, how is it failing or succeeding in that regard, what its new effects are, how it produces or fails to produce those effects, and how this shapes claims-making). We will thus need more deeply embedded ethnographic work on the state's many hands, its various meanings and practices, and the multifaceted ways ordinary people engage with them - in other words, more of the kind of work displayed in this special issue.

Acknowledgements Special thanks to Alison Coffey and Agueda Ortega for their comments on form and content - and to the students in the Readings in Ethnography graduate seminar at UT-Austin for, unknowingly to them, inspiring these pages with their queries about (and spirited criticism of) the craft of ethnography.

\section{References}

Álvarez-Rivadulla, María José. 2017. Squatters and the politics of marginality in Uruguay. New York: Palgrave Macmillan.

Arias, Enrique Desmond. 2009. Drugs and democracy in Rio de Janeiro: Trafficking, social networks, and public security. Chapel Hill: The University of North Carolina Press.

Auyero, Javier. 2006. Introductory note to politics under the microscope: Special issue on political ethnography I. Qualitative Sociology 29 (3): 257-259.

Auyero, Javier. 2012. Patients of the state: The politics of waiting in Argentina. Durham: Duke University Press Books.

Baiocchi, Gianpaolo, Elizabeth A. Bennett, Alissa Cordner, Peter Klein, and Stephanie Savell. 2013. Civic imagination: Making a difference in American political life. Boulder: Paradigm Publishers.

Bourdieu, Pierre, Jean-Claude Chamboderon, and Jean-Claude Passeron. 1991. The craft of sociology. Berlin; New York: de Gruyter.

Brodkin, Evelyn Z. 2017. The ethnographic turn in political science: Reflections on the state of the art. PS, Political Science \& Politics 50 (1): 131-134.

Conover, Ted. 2016. Immersion: A writer's guide to going deep. Chicago: University of Chicago Press.

Desmond, Matthew. 2017. Evicted: Poverty and profit in the American city. New York: Crown.

Elcioglu, Emine Fidan. 2020. Divided by the wall. First edition. Oakland: University of California Press.

Eliasoph, Nina. 2013. Making volunteers: Civic life after welfare's end. Princeton: Princeton University Press.

Geertz, Clifford. 2017. The interpretation of cultures. New York: Basic Books.

Jensen, Katherine, and Javier Auyero. 2019. Teaching and learning the craft: The construction of ethnographic objects. In Urban Ethnography, 16: 69-87. Research in Urban Sociology. Emerald Publishing Limited.

Lapegna, Pablo. 2016. Soybeans and power: Genetically modified crops, environmental politics, and social movements in Argentina. New York: Oxford University Press.

Lichterman, Paul. 2020. How civic action works: Fighting for housing in Los Angeles. Princeton: Princeton University Press.

Longo, Matthew, and Bernardo Zacka. 2019. Political theory in an ethnographic key. American Political Science Review 113 (4): 1066-1070.

Parvez, Z. Fareen. 2017. Politicizing Islam: The Islamic revival in France and India. New York; Oxford: Oxford University Press.

Perez, Marcos Emilio. 2018a. Becoming a Piquetero: Working-class routines and the development of activist disposition. Mobilization: An International Quarterly 23 (2): 237-253.

Perez, Marcos Emilio. 2018b. Institutional strengthening in a receding movement: The trajectory of Piquetero organizations between 2003 and 2015. Latin American Research Review 53 (2): 287-302.

Schatz, Edward. 2013. Political ethnography what immersion contributes to the study of power. Chicago: University of Chicago Press.

Sharma, Aradhana, and Akhil Gupta, eds. 2006. The Anthropology of the State: A Reader. Malden. Oxford: Wiley-Blackwell. 
Sullivan, Esther. 2018. Manufactured insecurity: Mobile home parks and Americans' tenuous right to place. Oakland: University of California Press.

Tarlau, Rebecca. 2019. Occupying schools, occupying land: How the landless workers movement transformed Brazilian education. New York: Oxford University Press.

Wacquant, Loïc. 2003. Ethnografeast: A progress report on the practice and promise of ethnography. Ethnography 4 (1): 5-14.

Wedeen, Lisa. 2015. Ambiguities of domination: Politics, rhetoric, and symbols in contemporary Syria. Chicago; London: University of Chicago Press.

Publisher's Note Springer Nature remains neutral with regard to jurisdictional claims in published maps and institutional affiliations.

Javier Auyero teaches in the Sociology Deparment at the University of Texas at Austin. 